\section{Історія Украӥни}

Ukrainian history
ISSN: 2411-6181(on-line); ISSN: 2311-9896 (print)

Current issues of social studies and history of medicine. Joint Ukrainian -Romanian scientific journal, 2018, №:4(20), P.60-67

UDK 94(477): 929+329.614 «1912/1993»

DOI 10.24061/2411-6181.4.2018.77

\author{
ЖИТТЕПИС ОРЕСТА ЗИБАЧИНСЬКОГО (1912-1993) \\ Ярослав АНТОНЮК, \\ Галузевий державний архів Служби безпеки України, \\ Київ (Україна), history.volyn@gmail.com \\ HISTOIRE DE LA VIE D'OREST ZYBACHYNSKY (1912-1993) \\ Yaroslav ANTONIUK, \\ Service de sécurité d'Ukraine Branch d'Archive d'État \\ Kyiv (Ukraine) \\ ORCID ID: 0000-0002-9419-5990; Researcher ID: E-3588-2017€
}

Антонюк Я. Жизнеописание Ореста Зыбачинского (1912-1993). Целью статьи является установление роли Ореста Зыбачинского в украинском освободительном движении. Методологическую основу исследования составляют принципы историзма и объективности. Научная новизна статьи заключается в раскрытии ранее неизвестных страниц жизни Ореста Зыбачинского и уточнении уже известных. Выводы. Доказано, что он основывал первые ячейки ОУН на Буковине и Донбассе, «Зарубежный центр» в Бухаресте и Интернационал Свободы в Мюнхене. Выяснено, что Орест Зыбачинский не создавал Буковинский курень. Развивая подпольную сеть на Донбассе, он опирался на украинскую интеллигенцию.

Ключевые слова: Черновиы, общество «Железняк», подполье ОУН, ПУН, «мельниковцы», походная группа «Пума», Донбасс, Интерначионал Свободы.

Вступ. Дослідження у сфері суспільних наук нерідко порушують актуальне питання ролі особи в історичних процесах. У цьому контексті важливе значення відіграють біографічні розвідки. Вони дають змогу краще осягнути події минулого, з'ясувати вплив на них дій окремих осіб. Однією із малодосліджених постатей, яка відіграла помітну роль в українському визвольному русі $\epsilon$ чернівчанин Орест Зибачинський. Масштаби його діяльності охоплювали не лише різноманітні регіони України, а й поширилися далеко за їі межі.

Метою дослідження є з'ясування ролі Ореста Зибачинського в українському визвольному русі. Методологічну основу дослідження складає принцип історизму, який вимагає розгляду всіх подій у відповідності 3 конкретноісторичними обставинами, а також принцип об'єктивності, який передбачає опору на факти в їх справжньому змісті. Застосовано конкретно-наукові методи історичних досліджень: хронологічний, логічний, ретроспективний, порівняльний та моделювання подій.

Історіографія та джерельна база. Постаті Ореста Зибачинчинського присвячували свої публікації: Юрій Клим'юк ${ }^{1}$, Микола Богайчук ${ }^{2}$ та Юхим Гусар ${ }^{3}$. Враховуючи усі попередні напрацювання, стаття опирається, передовсім, на невідомі архівні документи. Їх введення до наукового обігу допомогло грунтовніше розкрити тему дослідження.

Основна частина. Народився Орест 15 вересня 1912 р. у Чернівцях ${ }^{4}$ в сім’ї 23-річного Рудольфа Кіндратовича Зибачинського та 20-річної Ольги Михайлівни (дівоче прізвище Кобринська) $)^{5}$. На той час подружжя, яке мешкала в будинку на вул. Реджеле Кароль ${ }^{6}, 9$, уже виховувало 3 річного сина Мирослава-Ананія ${ }^{7}$. Сім'я Зибачинських належала до місцевої української інтелігенції. Цікавилася історією свого народу та підтримувала ідею державної самостійності. Разом із братом Орест навчався в четвертій українській гімназії, яка мала чудову бібліотеку. Книги прочитані у ній суттєво вплинули на світогляд молодих гімназистів.

Продовжив освіту Орест на юридичному факультеті Чернівецького університету ${ }^{8}$, а його брат Мирослав - електромеханічному факультеті Тімішоарського політехнічного інституту (Західна Румунія) ${ }^{9}$.

На той час серед української молоді Чернівців набирало популярності скаутське товариство «Пласт». Тому Орест відразу долучився до його діяльності. Разом із студентськими товаришами плавав човном до Галацу на Дунаї, де намагався відшукати могилу гетьмана Івана Мазепи ${ }^{10}$. Дещо пізніше Орест вступив до вступив до товариства міської молоді «Запоріжжя» ${ }^{11}$.

\footnotetext{
${ }^{1}$ Klymiuk Yu. Zybachynskyi Orest Rudolfovych [Zybachynsky Orest Rudolfovych], Bukovyna [Bukovyna], 2001, 25 lypnia, P. 3 [in Ukrainian]; Klymiuk Yu. Absoliut Oresta Zybachynskoho [Absolut of Orest Zybachynsky], Bukovynskyi zhurnal [Bukovynsky magazine], 2002, Ch. 1-2, P. 76-84 [in Ukrainian].

${ }^{2}$ Bohaichuk M. Zybachynskyi Orest Rudolfovych [Zybachynsky Orest Rudolfovych], Literatura i mystetstvo Bukovyny v imenakh: Slovnykdovidnyk [Literature and art of Bukovyna in names: Dictionary-directory], Chernivtsi, Bukrek, 2005, P. 101 [in Ukrainian].

${ }^{3}$ Husar Yu. «Ideoloh vyzvolnykh zmahan ukrainskoho narodu»: [15 travnia 100 rokiv vid dnia narodzhennia publitsysta, filosofa Oresta Rudolfovycha Zybachynskoho] [«Ideologist of the Ukrainian nation liberational struggle»], Bukovynske viche [Bukovinsky meeting], 2012, 11 travnia, P. 3 [in Ukrainian].

${ }^{4}$ Bohaichuk M. Zybachynskyi Orest Rudolfovych [Zybachynsky Orest Rudolfovych], Literatura i mystetstvo Bukovyny v imenakh: Slovnykdovidnyk [Literature and art of Bukovyna in names: Dictionary-directory], Chernivtsi, Bukrek, 2005, P. 101 [in Ukrainian].

${ }^{5}$ Haluzevyi derzhavnyi arkhiv Sluzhby bezpeky Ukrainy (HDA SBU) [Branch State Archive of Security Service of Ukraine], F. 2, Spr. 2376, Ark. 223 [in Russian].

${ }^{6}$ HDA SBU, F. 65, Spr. C-11861, Ark. 226-227 [in Russian].

${ }^{7}$ Ibid, F. 2, Spr. 2542 , Ark. 100 [in Russian].

${ }^{8}$ Mirchuk P. Narys istorii OUN. 1920-1939 roky [Essay on the OUN history. 1920-1939 years], Kyiv, 2007, P. 688 [in Ukrainian].

${ }^{9}$ HDA SBU, F. 2, Spr. 2376, Ark. 223 [in Russian].

${ }^{10}$ Klymiuk Yu. Zybachynskyi Orest Rudolfovych [Zybachynsky Orest Rudolfovych], Bukovyna [Bukovyna], 2001, 25 lypnia, P. 3 [in Ukrainian].

${ }^{11}$ Bukovyna. Yii mynule i suchasne [Bukovyna, its past and present], red. Kvitkovskoho D., Bryndzana T., Zhukovskoho A., ParyzhFiliadelfiia-Ditroit, Zelena Bukovyna, 1956, P. 812 [in Ukrainian].
}

Актуальні питання суспільних наук та історії медищини. Спільний українсько-румунський науковий журнал. 
Намагаючись згуртувати навколо себе рішучу молодь, він заснував 1930 р. в Чернівцях підпільну організацію «Ліга українських революціонерів», а в січні наступного року виступив ініціатором видання часопису «Самостійна думка». Активна діяльність молодого студента не залишилася поза увагою румунської поліції. У листопаді 1932 р. його разом із Захаром Бідняком було арештовано та відправлено під варту для проведення слідства. Однак, на щастя для юнаків, справа провалилася у суді. Зрештою адвокат Кость Радонець домігся у лютому 1933p. їх повного виправдання ${ }^{12}$.

Того ж року з Парижу до Чернівців прибули емісари Проводу ОУН Микола Сціборський та Мирослав Гузар ${ }^{13}$. На базі підпільних організацій «Легіон Українських революціонерів» та «Месники України» вони створили перший осередок ОУН на Буковині ${ }^{14}$. Його провідником призначили Сильвестра Никоровича ${ }^{15}$, а членами: Ореста Зибачинського («Орлана»), Дениса Квітковського («Квітку»), Івана Григоровича («Тріску») та Ореста Масікевича («Ореста») ${ }^{16}$.

У липні 1934 р. близько 40 учасників Чернівецького осередку ОУН заснували власну студентську групу «Залізняк» ${ }^{17}$. Ї̈і керівником став Іван Григорович ${ }^{18}$. Група видавала власний тижневик «Самостійність», який виходив за фінансової підтримки родини Гузарів ${ }^{19}$. Його поширенням та популяризацією займався Орест ${ }^{20}$. Хоча формально до групи «Залізняк» він не входив, неофіційно був іії лідером ${ }^{21}$.

25 березня 1937 р. в Чернівецькому театрі сталася надзвичайна подія. Учасники товариства «Буковинський Кобзар» проводили щорічні заходи із вшанування пам'яті Тараса Шевченка. Несподівано до них нахабно втрутилася румунська влада. На іiі вимогу учасники хору виконали гімн правлячої королівської династії. Це обурило юнаків із «Залізняка». Щойно хор почав співати державний гімн, юнаки почали його гучно пересвистувати ${ }^{22}$. Після цього шістьох винуватців «неподобства» арештувала жандармерія та скерувала для розслідування до військового трибуналу 8-ї дивізії армії. Суд над ними відбувся 20 квітня 1937 р. Більшість арештованих отримали терміни ув'язнення від 5-ти до 2-х років, які невдовзі замінили на сплату штрафу в розмірі 20 тисяч леїв ${ }^{23}$. На диво Оресту знову вдалося виправдатися та уникнути покарання ${ }^{24}$.

Остерігаючись нагляду поліції, того ж року він виїхав до Праги вивчати в комерційній академії право закордонної торгівлі. На той час столиця Чехословаччини була місцем осідку керівництва ОУН. Навчаючись, Орест познайомився з Олегом Кандибою («Ольжичем») та Андрієм Мельником. За їх рекомендацією пройшов ідеологічний вишкіл та мав зустріч з провідником ОУН Свгеном Коновальцем. За його особистим наказом Орест очолив Крайову екзекутиву ОУН на українських земель Румунії (Буковина, Бесарабія і Мармарощина) ${ }^{25}$.

Повернувшись на початку 1938 р. додому, він під псевдонімами «Коваль», «Орлик», «Олекса» та «Бакун», приступив до виконання поставлених доручень ${ }^{26}$. Призначив політичним референтом Дениса Квятковського, зв'язку - Сильвестра Некоровича, культурно-освітнім - Ореста Масікевич, пропаганди - Івана Григоровича та юнацтва Володимира Князьського ${ }^{27}$. Головні зусилля проводу в цей час зосередились на налагоджені пропаганди та розбудові підпільної мережі. За доволі короткий час Оресту вдалося налагодити постачання з Праги листівок та брошур $\mathrm{OУH}^{28}$. Крім того в будинках на вул. Василя Гєіна, 9 та вул. Гирла Mopi, 7 м. Чернівці було налагоджено виробництво власних листівок ${ }^{29}$. Десь у той час Орест одружився на 18річній студентці літературного факультету Чернівецького університету Марті Данилівні Мойсюк з с. Лужани Кіцманського $\mathrm{p}-$-ну $^{30}$. Дівчина повністю підтримувала погляди свого нареченого та також належала до ОУН ${ }^{31}$.

У лютому 1939 р. до Чернівців з Новоселиці повернувся Мирослав Зибачинський. На той час він уже мав добру ідеологічну підготовку ОУН. Тому Орест відразу залучив брата до пропагандистського рейду північною Буковиною. Крім них, до агітаційної групи увійшли: Марта Зибачинська («Мар»), Сорочинський («Туня»), а також Мирослав, Карп та Марія Роговські. Підпільники відвідали Вижницю, Селятин та інші населені пункти. Поряд із агітацією, вони вивчали перспективи розбудови мережі ${ }^{32}$.

\footnotetext{
${ }^{12}$ Fostii I. Diialnist OUN na Bukovyni u 1940-1941 rr. [OUN activities in Bukovina in 1940-1941.], Z arkhiviv VUChK-HPU-NKVDKHB [From the archives of the VUCHK-GPU-NKVD-KGB], 2000, 2/4, P. 454-457 [in Ukrainian].

${ }^{13}$ HDA SBU, F. 2, Spr. 2543, Ark. 27 [in Russian].

${ }^{14}$ Fostii I. Diialnist OUN na Bukovyni u 1940-1941 rr. [OUN activities in Bukovina in 1940-1941.], Z arkhiviv VUChK-HPU-NKVDKHB [From the archives of the VUCHK-GPU-NKVD-KGB], 2000, 2/4, P. 454 [in Ukrainian].

${ }^{15}$ HDA SBU, F. 2, Spr. 1495, Ark. 167 [in Russian].

${ }^{16}$ Ibid, F. 2, Spr. 2542, Ark. 88 [in Russian].

${ }^{17}$ Ibid, F. 2, Spr. 2376, Ark. 197 [in Russian].

${ }^{18}$ Ibid, F. 2, Spr. 1495, Ark. 167 [in Russian].

${ }^{19}$ Mandryk-Melnychuk M. Rodyna Huzariv - liubov do Ukrainy kriz viky [The Husar family - love for Ukraine through the ages], Ukrainske slovo-Litavry [Ukrainian word-Lytavry], № 6, 2016, P 13 [in Ukrainian].

${ }^{20}$ Mandryk M. Ukrainskyi natsionalistychnyi rukh 1920-30-kh rr. na pivnichnii Bukovyni u svitli rumunskykh arkhivnykh dokumentiv [Ukrainian nationalist movement of the 1920's and 1930's in northern Bukovina explicated by Romanian archival documents], Ukrainskyi vyzvolnyi rukh [Ukrainian liberation movement], Lviv, 2004, Zbirnyk 3, P. 92 [in Ukrainian].

${ }^{21}$ HDA SBU, F. 65, Spr. C-11861, Ark. 17 [in Russian].

${ }^{22}$ Ibid, F. 2. Spr. 2013, Ark. 109 [in Russian].

${ }^{23}$ Mandryk M. Ukrainskyi natsionalistychnyi rukh 1920-30-kh rr. na pivnichnii Bukovyni u svitli rumunskykh arkhivnykh dokumentiv [Ukrainian nationalist movement of the 1920's and 1930's in northern Bukovina explicated by Romanian archival documents], Ukrainskyi vyzvolnyi rukh [Ukrainian liberation movement], Lviv, 2004, Zbirnyk 3, P. 96 [in Ukrainian].

${ }^{24}$ Strohyi prysud u Chernovetskomu protsesi. 5-okh obvynuvachenykh zasudyly na 13 rokiv viaznytsi [A strict sentence in the Chernivtsi process. Five of the accused were sentenced to 13 years of imprisonment], Dilo [Діло], 1937, 24 kvitnia, Р. 1 [in Ukrainian].

${ }^{25}$ HDA SBU, F. 2, Spr. 2376, Ark. 223 [in Russian].

${ }^{26}$ Ibid, F. 65, Spr. C-11861, Ark. 62 [in Russian]

${ }^{27}$ Ibid, F. 2, Spr. 2543, Ark. 27 [in Russian].

${ }^{28}$ Ibid, F. 2, Spr. 2542, Ark. 99 [in Russian].

${ }^{29}$ Ibid, F. 65, Spr. C-11861, Ark. 55 [in Russian].

${ }^{30}$ Ibid, F. 65, Spr. C-11861, Ark. 13 [in Russian]

${ }^{31}$ Ibid, F. 2, Spr. 2542, Ark. 196 [in Russian].

${ }^{32}$ Ibid, F. 2, Spr. 2376 , Ark. 223 [in Russian].
} 


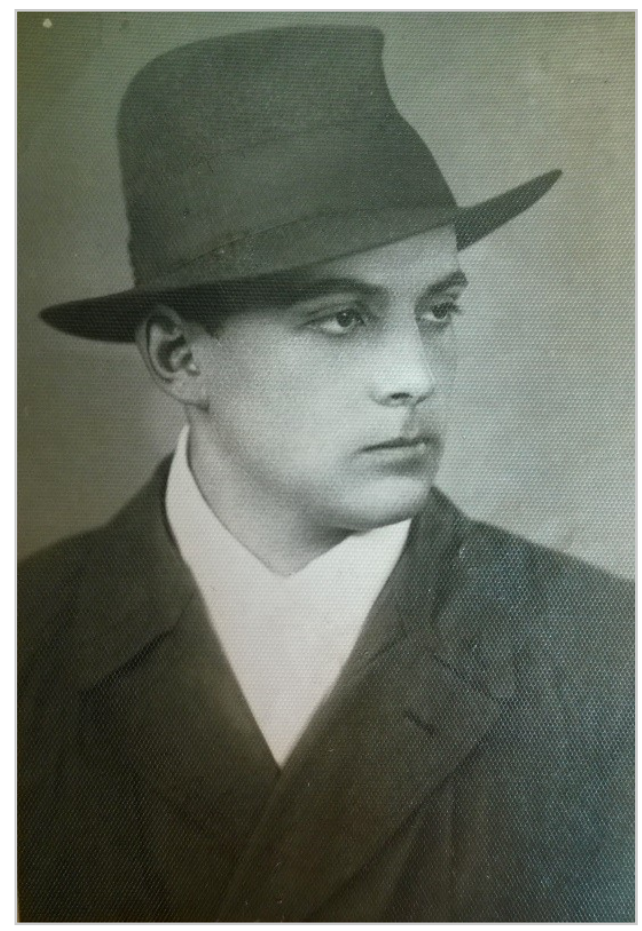

Орест Зибачинський

Весною 1939 р. Орест викликав до Чернівців керівника Карпачівського підрайону ОУН Єлизара Дарійчука («Сокола»). Зустріч відбулася на вулиці Білій біля військового полігону. Назвавши пароль «Бар - Базар», підпільники впродовж півгодини обговорювали організаційні справи. «Сокіл» прозвітував стосовно розвитку осередку та кількості нових членів. Наприкінці Орест наказав викликати на зустріч в липні районного провідника Ореста Гаджу («Клима»). Однак того місяця його призвали до армії та на зустріч знову прибув «Сокіл». Цього разу Орест призначив Дарійчука районним провідником й наказав передати підрайонному Олексію Додюку («Ворону») 3 с. Виженка організаційні інструкції. Їх суть полягала у необхідності розширення впливу на гірські села.

Через місяць відбулася наступна зустріч «Сокола» та Ореста. Місцем було обраний магазин на вулиці Марашешти в Чернівцях. Почувши умовлений пароль, продавець Петро Войновський («Іван») відвів візитера до однієї 3 кімнат. Невдовзі туди прибув «Бакуна». Цього разу підпільники обговорювали підготовку нових підпільників. Орест наголошував, що «не потрібна гнатися за кількістю, достатньо мати три людини на село, які здатні працювати». Стосовно роботи в румунських селах та «несвідомих» українських, рекомендував призначити підпільників 3 інших населених пунктів. Зауважив, що оунівцю нема шляху назад. Зрадників доведеться ліквідовувати. Робити це пот- рібно тихо, ніби людина пропала безвісти. Потрібно слідкувати за усіма чужинцями, які прибувають в села. За людьми, які надто цікавляться справами підпілля. Підозрілих слід заносити в «чорні списки».

Наступну зустріч «Соколу» Орест призначив на 15вересня. Проте районного провідника призвали в армії. Потрапивши до Чернівецької військової частини, підпільнику вдалося відпроситися у коменданта на кілька годин та зв'язатися 3 керівником. Цього разу «Сокіл» отримав від Ореста інструкції «чим потрібно цікавитися в армії та яких людей підшуковувати» ${ }^{33}$.

У той же час, на призовному пункту в Садгорі, Мирослава Зибачинського записали до 12-го артилерійського полку. Через сім місяців, як цінного спеціаліста, його відправили до залізничної майстерні в Яссах. За вказівкою брата, Мирослав організував там осередок ОУН. 3 собою він взяв 20 оунівських книг, 20 значків з тризубами, а також 50 листівок з зображенням гетьманів та лідерів $\mathrm{OVH}^{34}$.

Наполеглива організаційна робота Ореста поступово приносила результати. Восени 1939 р. Буковинська крайова екзекутива ОУН уже охоплювала три надрайони: Північний (Кіцманський, Заставнівський, Садгорський, Глибокський, Новоселицький та Хотинський р-ни); Західний (Путильський, Вижницький, Вашковецький і Строжинецький р-ни); Південний (Сучавський та Радівцівський райони $)^{35}$. Було створено розвідувальний сектор на чолі з Карпом Роговським. До його завдань належало виявлення агентів Сігуранци, а також збір інформації про діяльність прихильників УНДО та редакції газети «Час» на чолі з Залозецьким ${ }^{36}$.

Одначе хід звичних подій різко змінила міжнародна політика. Впродовж 28 червня - 3 липня 1940 р. Радянський союз анексував Північну Буковину та Бессарабію. За декілька днів до цього ${ }^{37}$, рятуючись від репресій, Орест переїхав в м. Радівці Сучавського повіту ${ }^{38}$. Керівництво Чернівецьким обласним проводом ОУН він передав заступнику Дмитру Яремчуку ${ }^{39}$. Залишаючись при цьому його зверхником ${ }^{40}$. На початку жовтня 1940 р. новим обласним провідником став Віктор Кулішір ${ }^{41}$. Одразу після цього організаційний референт Юрій Фурман привіз йому від Зибачинського інструкції. У них вимагалося берегти кадри, відмовитися від проведення антирадянських акцій та припинити набір до підпілля молоді ${ }^{42}$. Наприкінці березня 1941 р. Орест знову відправив до Чернівців зв'язкового із вказівкою не визнавати влади Степана Бандери та вважати його зрадником. Однак обласний провід вирішив тимчасово приховати від рядових членів новину про чвари між керівниками ОУН ${ }^{43}$.

Вочевидь у цей час між обласним та Крайовим проводами виникло певне непорозуміння. Підпільники в радянському запіллі вважали, що їх керівництво відсиджується на еміграції. Увесь негатив цих настроїв

\footnotetext{
${ }^{33}$ Ibid, F. 2. Spr. 2013, Ark. 119-122 [in Russian].

${ }^{34}$ Ibid, F. 2, Spr. 2376, Ark. 223 [in Russian].

${ }^{35}$ Ibid, F. 2, Spr. 2543, Ark. 27 [in Russian].

${ }^{36}$ Ibid, F. 65, Spr. C-11861, Ark. 27 [in Russian].

${ }^{37}$ Ibid, F. 65, Spr. C-11861, Ark. 23 [in Russian].

${ }^{38}$ Klymiuk Yu. Zybachynskyi Orest Rudolfovych [Zybachynsky Orest Rudolfovych], Bukovyna [Bukovyna], 2001, 25 lypnia, P. 3 [in Ukrainian].

${ }^{39}$ HDA SBU, F. 65, Spr. C-11861, Ark. 101 [in Russian].

${ }^{40}$ Reabilitovani istoriieiu [Rehabilitated by history]. Naukovo-dokumentalna seriia knyh. Red. kolehiia: hol. Fostii I. ta in., Chernivtsi, Knyha Pamiati Ukrainy, 2007, P. 57 [in Ukrainian].

${ }^{41}$ Litopys UPA. Nova seriia. T. 19: Pidpillia OUN na Bukovyni. 1943-1951 [OUN underground in Bukovyna. 1943-1951]. Dokumenty i materialy, uporiadnyk D. Prodanyk, Kyiv-Toronto, 2012, P. 28 [in Ukrainian].

${ }^{42}$ Fostii I. Diialnist OUN na Bukovyni u 1940 - 1941 rr. [OUN activities in Bukovina in 1940 - 1941.], Z arkhiviv VUChK-HPU-NKVD$K H B$ [From the archives of the VUCHK-GPU-NKVD-KGB], 2000, 2/4, P. 460 [in Ukrainian].

${ }^{43}$ HDA SBU, F. 2, Spr. 2013, Ark. 134 [in Russian].
} 
спрямувався на Ореста Зибачинського, якого звинувачували в неналежному виконанні обов'язків крайового провідника.

20 серпня 1941 р. політичний референт Буковинського обласного проводу Михайло Колотило («Кобзар») написав звіт про становище підпілля. Організаційна робота Зибачинського у ньому характеризувалася доволі негативно: «...В наступні роки Організація зазнає застою й пасивності. Все зводилося до звичайних балачок. Зибачинський не зумів витворити справжньої провідної революційної еліти, а вщеплював у людей, яких він виховував свої прикмети: дурну, хворобливу амбіцію, жадобу кар'єри. Для деяких організація була засобом наживи. Він витворив на Буковині амбітно-виключні погляди: «Щоб тільки я, а не хто інший». В такому стані безділля і розкладу з'явилась Організація перед приходом большевиків. На селі мало працювалось: рівень свідомості був низький» ${ }^{44}$.

У цей час Орест зосередився на організаційній роботі в Румунії. Восени 1940 р. він переїхав до Бухаресту, де створив «Закордонний центр» (Румунський провід) $\mathrm{OУH}^{45}$. Культурно-драматичну секцію у ньому очолював Іван Григорович, літературно-пропагандистський відділ - Орест Масікевич, фізкультурну секцію - Володимир Тодорюк («Тур») та економічно-фінансовий відділ - Сильвестр Никорович. Помічниками провідника були Василь Якубович та Денис Квятковський ${ }^{46}$.

Першим їх заходом стало захоплення контролю над спортивним товариство «Буковина», яке уже давно діяло в Бухаресті. 3 цією метою до нього записалися усі місцеві оунівці. На чергових зборах вони замінили старого голову товариства Іларія Данилюка на нового - Ореста Масікевича. За ініціативи Зибачинського, оунівці розпочали тричі на тиждень читати українським студентам курс лекцій 3 політики, історії та літератури ${ }^{47}$. Найбільш здібних він особисто залучив підпільної мережі. Зокрема, студентів Бухарестського університету Василя Нацюка, Володимира Жуковського та інших ${ }^{48}$. Тоді ж, згідно спогадів Петра Войновського («Василя»), Орест створив молодіжну групу, яка «відроджувала» давнє слов'янське язичництво, вшановуючи Дажбога й Перуна ${ }^{49}$.

У травні 1941 р. Зибачинський та Масікевич виїжджали до Берліну для отримання агітаційної літератури. Тоді ж вони зустрілися з Андрієм Мельником ${ }^{50}$. Наслідком цих перемовин було передання Зибачинським посади про- відника «Закордонного центру» Масікевичу ${ }^{51}$. Ймовірно також за вказівкою Мельника, на початку червня 1941 р. Орест пройшов німецький вишкіл в школі на вулиці Ізвор м. Бухарест ${ }^{52}$. Водночас він підготував три варіанти стратегії «Закордонного центру» відповідно до позиції німців: 1) підтримки - створити та очолити українську визвольну армію, 2) нейтральної - розгорнути пропагандистську роботу на території колишніх східних, центральних та південних областей УРСР, 3) ворожої - перейти у підпілля ${ }^{53}$.

Головним завданням Зибачинського на той час стало створення Похідного підрозділу ПУН ${ }^{54}$. Внаслідок переговорів із німцями, з 60-ти українських студентів (3 них лише 25 оунівців), було сформовано загін Абверу № 101. Крім функції перекладачів, їх завданням було надання допомоги у формуванні органів місцевого самоврядування. Представником від «мельниківців» у групі був Орест Масікевич, а від німців - Олександр Пулюй (син відомого фізика). За першими літерами їх прізвищ виникла й неофіційна назва підрозділу - «Пума» ${ }^{55}$. Посаду провідника «Закордонного центру» Масікевич передав Івану Григоровичу, якого уже наступного арештувала румунська поліція ${ }^{56}$.

Перший адміністративний вишкіл групи відбувався в м. П'ятра-Нямц. Через кілька днів, 4 липня 1941 р. їх перевели до м. Ясси, де проводилося інтенсивне військове навчання ${ }^{57}$. Після нього Зибачинському та Масікевичу видали пістолети. Крім того на озброєнні в групі «Пума» було 2 автомати $^{58}$.

У цей час Оресту вдалося зустрітися з братом та забрати 20 раніше виданих брошур ${ }^{59} .12$ липня група «Пума» увійшла до Кишинева, де до них долучилося ще 20 буковинців та галичан 3 колишніх червоноармійців. 29 липня вступила до прикордонного містечка Дубосари та приєдналася до 72-ї піхотної дивізії 11-ої армії «Південь» ${ }^{60}$. Ії завданням на той час був збір штабних трофейних документів (накази, шифри, коди) розбитих німцями частин Червоної армії ${ }^{61}$.

У іï складі 18 серпня 1941 р. «Пума» перейшла через понтонний міст лиман Інгул та прибула до Миколаєва. Там вони зустріли іншу Похідну групу на чолі з Богданом Сірецьким, яка рухалася в напрямку Кубані. Між «мельниківцями» одразу розпочалися перемовини про спільні дії, що привернуло увагу гестапо. Зважаючи небезпеку арештів, Масікевич та Пулюй вирішили свою групу розпустили. Після цього буковинські «мельниківці» роз’і-

\footnotetext{
${ }^{44}$ Serhiichuk V. Ukrainskyi zdvyh: Prykarpattia. 1939-1955 [Ukrainian Shift: Prykarpattya. 1939 - 1955], Kyiv, Ukrainska Vydavnycha Spilka, 2005, P. 130 [in Ukrainian].

${ }^{45}$ HDA SBU, F. 2, Spr. 1495, Ark. 28 [in Russian].

${ }^{46}$ Ibid, F. 2, Spr. 2542, Ark. 5-6 [in Russian].

${ }^{47}$ Ibid, F. 2, Spr. 2543, Ark. 248 [in Russian].

${ }^{48}$ Ibid, F. 2, Spr. 2542, Ark. 99 [in Russian].

${ }^{49}$ Voinovskyi P. Moie naivyshche shchastia: Spomyny [My greatest happiness: Memories], Kyiv, Vydavnytstvo imeni Oleny Telihy, 1999, P. 160

-165 [in Ukrainian].

${ }^{50}$ HDA SBU, F. 2, Spr. 1495, Ark. 17 [in Russian].

${ }^{51}$ Ibid, F. 2, Spr. 2543, Ark. 141, 235 [in Russian]

${ }^{52}$ Ibid, F. 2, Spr. 2543, Ark. 118 [in Russian].

${ }^{53}$ Ibid, F. 2, Spr. 2543, Ark. 115-116 [in Russian].

${ }^{54}$ Ibid, F. 65, Spr. C-11861, Ark. 23 [in Russian].

${ }^{55}$ Ibid, F. 2, Spr. 2376, Ark. 223 [in Russian].

${ }_{56}^{56}$ Ibid, F. 2, Spr. 2542, Ark. 5-6 [in Russian].

${ }^{57}$ Bolianovskyi A. Ukrainski viiskovi formuvannia v zbroinykh sylakh Nimechchyny (1939-1945) [Ukrainian military formations in the armed forces of Germany (1939-1945)], Lviv, Misioner, 2003, P. 75-77 [in Ukrainian].

${ }^{58}$ HDA SBU, F. 65, Spr. C-11861, Ark. 189 [in Russian].

${ }^{59}$ Ibid, F. 2, Spr. 2376, Ark. 223 [in Russian].

${ }^{60}$ Bolianovskyi A. Ukrainski viiskovi formuvannia $v$ zbroinykh sylakh Nimechchyny (1939-1945) [Ukrainian military formations in the armed forces of Germany (1939-1945)], Lviv, Misioner, 2003, P. 77-79 [in Ukrainian].

${ }^{61}$ HDA SBU, F. 65, Spr. C-11861, Ark. 133 [in Russian].
} 


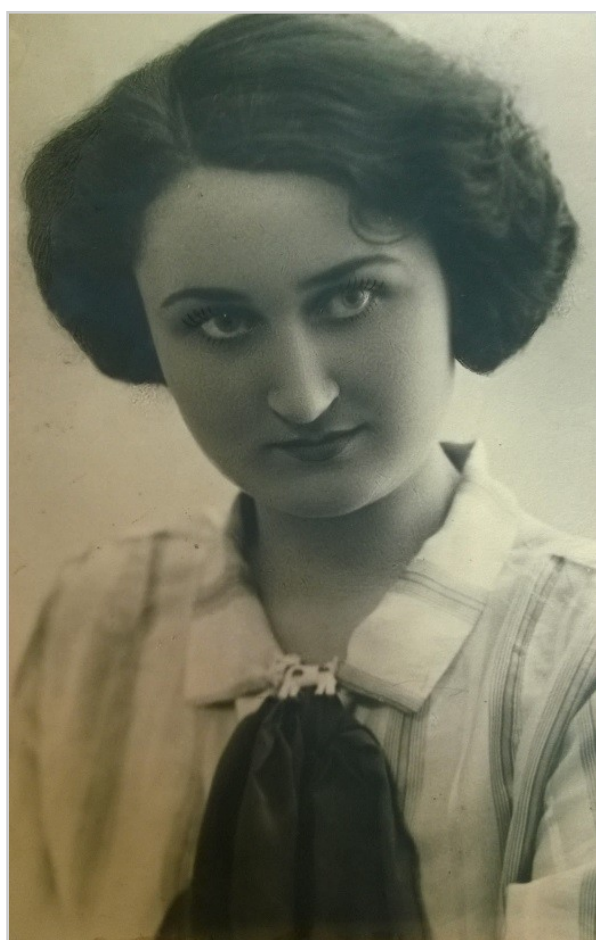

Марта Зибачинська (фото 1940 р.)

халися будувати свої осередки по усій центральній, південній та східній Україні ${ }^{62}$.

Орест вирушив до Вінниці ${ }^{63}$, ймовірно дізнавшись, що там перебуває його дружина. За той час Марті довелося немало пережити. За часів радянської анексії Буковини вона залишилася Чернівцях ${ }^{64}$. Мешкала на вулиці Єремія Мавіла, 56, заробляючи на життя репетиторством. 24жовтня 1940 р. iї арештували органи НКДБ та відправили до в'язниці ${ }^{65}$. Пішовши на «співпрацю із слідством», Марта назвала прізвища 20-ти членів товариства «Запорожжя», 11 - «Чорноморе», 11 - «Залізняк» ${ }^{66}$, а також погодилася працювати в агентом. Після цього 14 квітня 1941 р. іiї звільнили ${ }^{67}$.

Опинившись на волі підпільниця одразу порвала зв'язки з органами НКВС та перейшла на нелегальне становище. На початку липня 1941 р. Марта вступила у якості референта пропаганди до штабу Буковинського куреня ${ }^{68}$. Однак невдовзі у неї виник конфлікт з курінним Петром
Войновським («Василь»). Причини його достеменно невідомі. Існують різні версії - особиста образа, звинувачення в некомпетентності, співпраці з органами НКВС, гестапо та «бандерівцями» ${ }^{69}$. Внаслідок цього конфлікту Марта залишилася із частиною куреня в Жмеринці ${ }^{70}$. Лише наприкінці серпня 1941 р. вона зважилася прибути до Вінниці, де зустрілася після довгої розлуки з чоловіком ${ }^{71}$.

На початку жовтня 1941 р. подружжя Зибачинських прибуло до Києва, де наштовхнулося «холодну» зустріч Войновського ${ }^{72}$, який саме оселився в квартирі біля пам'ятника Тарасу Шевченку ${ }^{73}$. У той час Орест навідався до Єлизара Дарійчука («Сокола»), який працював в кримінальній поліції Бердичева. Під час розмови із давнім товаришем він розповів, що «Василь» погрожував видати його німцям. Обіцяв, що за це він обов'язково постане перед Революційним трибуналом ${ }^{74}$.

Вочевидь під тиском обставин, повернувшись до Києва, Орест вирішив їхати розбудовувати підпільну мережу на Донбасі ${ }^{75}$. До Зибачинських цій подорожі приєднався 35 -річний підпільник зі Львова - Михайловський та ще один його невідомий «мельниківець». На початку листопада 1941 р. згадана група залишила Київ. Надалі їхній маршрут пролягав через Полтаву до м. Сталіно (нині Донецьк), яке нещодавно майже без бою зайняли німецько-італійські війська ${ }^{76}$. Оселилася похідна група Зибачинського в квартирі на третьому поверсі будинку № 154 за адресою «8-ма лінія». Практично одразу їм вдалося налагодити зв'язок 3 місцевими оунівцями: шкільним вчителем Іллею Шумилом, техніком відділу радіомовлення міської управи Максимом Петренком, Борисом Гончаренком, Григорієм Дяченком, Іваном Солдаком та Петром Іваницьким ${ }^{77}$.

На загальній нараді Орест представився їм як «пан сотник» ${ }^{78}$, провівши 3 кожним особисту бесіду. Поступово до осередку Зибачинського долучилося ще близько десяти місцевих українців. Більшість 3 них займали певні посади в окупаційній адміністрації. Серед них: бухгалтер харчової лабораторії Латанський, комендант житлового відділу Буряк, Бобенко, Левченко, Радченко та інші. Завдяки ним Зибачинський розгорнув роботу осередку. Займався розбудовою «Просвіти», організував розповсюдження «мельниківської» агітації в Сталіно та районах області. Зокрема, на початку грудня 1941 р. Гончаренко та Шумило, під виглядом закупівлі продуктів, виїжджали до сіл Селидівського р-ну. Виконуючи завдання Ореста, вони

\footnotetext{
${ }^{62}$ Bolianovskyi A. Ukrainski viiskovi formuvannia $v$ zbroinykh sylakh Nimechchyny (1939-1945) [Ukrainian military formations in the armed forces of Germany (1939-1945)], Lviv, Misioner, 2003, P. 80-86 [in Ukrainian].

${ }^{63}$ HDA SBU, F. 65, Spr. C-11861, Ark. 190 [in Russian].

${ }^{64}$ Ibid, F. 65, Spr. C-11866, Ark. 14 [in Russian].

${ }^{65}$ Musiienko I. Etnichnyi sklad represovanykh na pivnichnii Bukovyni v 1940-1950-kh rr. [The ethnic composition of the repressed in the northern Bukovyna in the 40's and 50's of the XXth century.], KhKh st., Materialy do ukrainskoi etnolohii [Materials of Ukrainian ethnology], № 6 (9), 2007, P. 105 [in Ukrainian].

${ }^{66}$ Fostii I. Diialnist OUN na Bukovyni u 1940-1941 rr. [OUN activities in Bukovina in 1940 - 1941.], Z arkhiviv VUChK-HPU-NKVD$K H B$ [From the archives of the VUCHK-GPU-NKVD-KGB], 2000, 2/4, P. 457 [in Ukrainian].

${ }^{67}$ HDA SBU, F. 2, Spr. 1495, Ark. 37 [in Russian].

${ }^{68}$ Ibid, F. 65, Spr. C-11866, Ark. 45 [in Russian].

${ }^{69}$ Ibid, F. 2, Spr. 2542, Ark. 196 [in Russian].

${ }^{70}$ Chechva V. Bukovynskyi kurin [Bukovynsky hut], Shliakh Peremohy [Path to Victory], 1980, 30 lystopada, P. 2. [in Ukrainian].

${ }^{71}$ HDA SBU, F. 2, Spr. 2376, Ark. 289 [in Russian].

${ }^{72}$ Radchenko Yu. Znovu pro «suchykh ditei» abo Moia vidpovid Volodymyru Staryku [Again about «dog children» or My answer to Volodymyr Staryk]. Chastyna druha, Ukraina Moderna [Ukraina Moderna], 2017, URL: http://uamoderna.com/blogy/yurij-radchenko/starik2 [in Ukrainian].

${ }_{74}^{73}$ HDA SBU, F. 6, Spr. 55363, T. 2, Ark. 95 [in Russian].

${ }^{74}$ Ibid, F. 2, Spr. 2013 , Ark. 148 [in Russian].

${ }^{75}$ Ibid, F. 2, Spr. 2486, Ark. 72 [in Russian].

${ }^{76}$ Ibid, F. 2, Spr. 2679, Ark. 229 [in Russian].

${ }_{78}^{77}$ Ibid, F. 2, Spr. 2699, Ark. 6-7, 56-57 [in Russian].

${ }^{78}$ Nikolskyi N. Pidpillia OUN(b) na Donbasi [OUN(b) underground on Donbas territories], Kyiv, Instytut istorii NAN Ukrainy, 2001, P. 37 [in Ukrainian].
} 
агітували місцеву інтелігенцію приєднуватися до підпільної мережі. Зокрема, в с. Красне (нині Сонцівка) завітали до вчителя Горбаня, а в селищі Олександрівка - до вчителів Михайла Шелудька та Герасима Титарчука ${ }^{79}$. Відомо також, що для налагодження зв'язку з українським осередком в Таганрозі, туди виїжджав Іваницький ${ }^{80}$. Водночас Opecn взаємодіяв 3 іншими «мельниківськими» групами. Наприклад, здійснив наприкінці січня 1942 р. візит до Запоріжжя ${ }^{81}$, де заснував підпільний осередок ${ }^{82}$.

На початку лютого 1942 р. групу Зибачинського арештувала німецька поліція ${ }^{83}$ та відправила на слідство до Києва ${ }^{84}$. Однак під час конвоювання відбулася типова для тих часів подія. Ув'язнені та охоронці потрапили під бомбардування. Скориставшись панікою, «мельниківцям» вдалося втекти ${ }^{85}$.

Після цього подружжя Зибачинських вдруге прибуло до Києва. На той час німці проводили арешти оунівців. Було схоплено Олену Телігу, Івана Рогача та багато інших визначних діячів, яких невдовзі розстріляли в Бабиному Яру $^{86}$. Рятуючись від неминучого арешту, Зибачинські виїхали на Волинь. У липні 1942 р. вони прибули до Рівного. Орест відразу встановив зв'язок з обласним провідником та водночас керівником драматичного театру Анатолі$€ м$ Довгопольським («Демо»), який влаштував його до себе на роботу ${ }^{87}$. Тоді ж в сім'ї Зибачинських народився син ${ }^{88}$. Поряд із роботою в театрі, Орест під псевдонімами «Байрон» та «Барда» очолював Волинський обласний інспекторат ПУН ${ }^{89}$. Окрім «Демо», соратниками Зибачинського на той час були: Олег Штуль («Жданович»), Михайло Медвецький («Богун») та Петро Остапчук ${ }^{90}$. У підпорядкуванні Інспекторату знаходилося Рівненський та Луцький обласні проводи, які охоплювали шість округ: Дубенську, Рівненську, Костопільську, Луцьку, Володимир-Волинську та Ковельську ${ }^{91}$. Ймовірно у цей час Орест координував на Поліссі переговори ПУН з керівником Української народно-революційної армії (УНРА) Тарасом Боровцем («Бульбою»). Однак документального підтвердження цьому поки що не знайдено.

На початку 1943 р. сім'я Зибачинських переїхала до Луцька, де мешкала під прізвищем Дзюбинських ${ }^{92}$. Про цей період діяльності Ореста збереглося небагато даних.

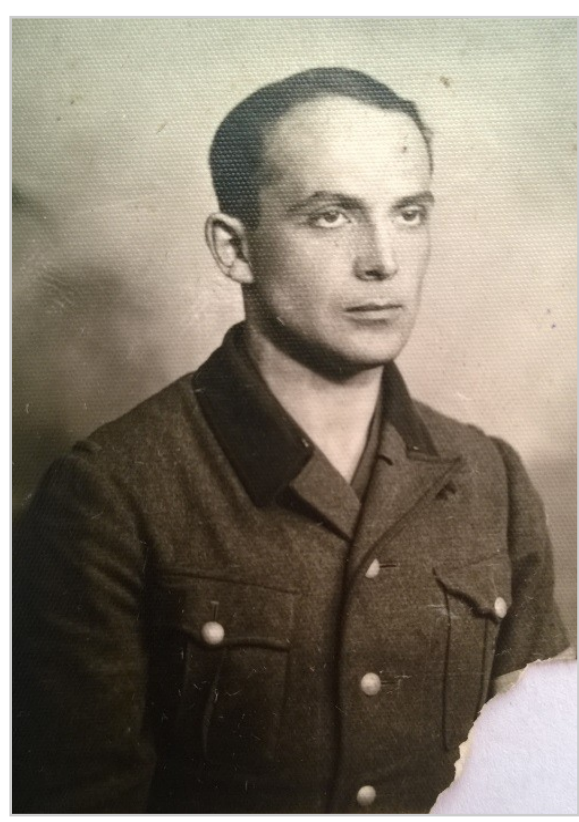

Орест Зибачинський (фото 1942 р.)

Відомо, що він долучився у вересні 1943 р. до формування Українського легіону самооборони (31-й батальйон СД) $)^{93}$, який був став найбільшим «мельниківським» військовим підрозділом ${ }^{94}$.

Наприкінці 1943 р. сім'я Зибачинських виїхала в м. Броди ${ }^{95}$, а звідти - до Львова. Через кілька тижнів вони перебралися до Відня, а невдовзі - до Зальцбурга ${ }^{96}$, де Орест очолив мережу ПУН Австрії ${ }^{97}$.

Натомість органи НКДБ помилково вважали, що у цей час він здійснював на території Польщі підготовку німецьких диверсантів ${ }^{98}$. Вірогідно насправді прийнятим за Зибачинського «Ковалем» був хорунжий Українського легіону самооборони родом з Кременеччини ${ }^{99}$.

Відомо, що восени 1944 р. Зибачинський приймав участь в ухваленні керівництвом ПУН «Братиславської директиви». Під час цієї наради в готелі «Регіна» було остаточно відхилено збройний шлях протистояння радянській владі та зосереджено увагу на пропагандистській робо-

\footnotetext{
${ }^{79}$ HDA SBU, F. 2, Spr. 2699, Ark. 59-70, 129-131 [in Russian].

${ }^{80}$ Ukrainskyi rukh na Donechchyni 1917-1958. Lektsiia Oleksandra Dobrovolskoho [Ukrainian movement in Donetsk region from 1917 to 1958. The lecture by Olexander Dobrovolsky], Istorychna pravda [Historical truth], 2015, URL: http://www.istpravda.com.ua/articles/2015/12/28/148842/ [in Ukrainian].

${ }^{81}$ HDA SBU, F. 2, Spr. 2542, Ark. 99 [in Russian].

${ }^{82}$ Ibid, F. 65, Spr. C-11861, Ark. 58 [in Russian].

${ }^{83}$ Panchenko O. I natsionalist - patriot, i demokrat (Z nahody 95-richchia Yevhena Stakhiva) [Nationalist and patriot, and democrat (on the occasion of the 95th anniversary of Yevhen Stakhiv)], Svoboda [Liberty], 2013, 20 veresnia, P. 12 [in Ukrainian]

${ }^{84}$ HDA SBU, F. 2, Spr. 2699, Ark. 95 [in Russian].

${ }^{85}$ Buriak V. «Ia chlen SUM na Ridnykh Zemliakh». Uryvky z lysta do redaktsii [«I am a CYM member on native lands». Excerpts from a letter to the editor], Homin Ukrainy [Homin Ukrainy], 1978, 18 travnia, P. 3 [in Ukrainian].

${ }^{86}$ HDA SBU, F. 2, Spr. 2681, Ark. 32 [in Russian].

${ }^{87}$ Ibid, F. 65, Spr. S-9134, T. 1, Ark. 22 [in Russian].

${ }^{88}$ Klymiuk Yu. Absoliut Oresta Zybachynskoho [Absolut of Orest Zybachynsky], Bukovynskyi zhurnal [Bukovynsky magazine], 2002, Ch. 1-2, P. 80 [in Ukrainian].

${ }^{89}$ HDA SBU, F. 2, Spr. 2030, Ark. 31 [in Russian].

${ }^{90}$ Ibid, F. 2, Spr. 2680, Ark. 271 [in Russian].

${ }^{91}$ Ibid, F. 2, Spr. 1494, Ark. 71 [in Russian].

${ }_{92}^{92}$ Ibid, F. 2, Spr. 2194, Ark. 126 [in Russian].

${ }^{93}$ Ibid, F. 65, Spr. C-11861, Ark. 11 [in Russian].

${ }^{94}$ Ibid, F. 2, Spr. 2746, Ark. 29, 116 [in Russian].

${ }^{95}$ Ibid, F. 65, Spr. C-11861, Ark. 100 [in Russian].

${ }^{96}$ Ibid, F. 2, Spr. 1495, Ark. 37 [in Russian].

${ }^{97}$ Ibid, F. 2, Spr. 2699, Ark. 198 [in Russian].

${ }^{98}$ Ibid, F. 2, Spr. 2679, Ark. 223; Spr 2680, Ark. 271-272, 325 [in Russian].

${ }^{99}$ Karkots-Vovk M. Vid Voronizha do Ukrainskoho lehionu samooborony [From Voronizh to the Ukrainian Legion of Self-Defense], Rivne, Soiuz Veteraniv Ukrainskoho Rezystansu, 2002, P. 119 [in Ukrainian].
} 
Ti. ${ }^{100}$

Влітку 1945 р. сім’я Зибачинських переїхала до Мюнхена та оселилася в будинку за адресою: МюнхенЛяйн, Фірстеррідерштрассе, $155^{101}$. Тоді ж Орест вступив до Вищої економічної школи ${ }^{102}$. У той час він був одним наближених до Андрія Мельника керівників ${ }^{103}$. Очолюючи фінансовий сектор ПУН ${ }^{104}$ та водночас румунський напрямок роботи ${ }^{105}$.

У грудні 1946 р. Орест заснував та очолив організацію Інтернаціонал Свободи («мельниківський» аналог Антибільшовицького блоку народів») ${ }^{106}$. До іiі складу входили литовська, грузинська, угорська, болгарської, сербська, хорватська, чеська, словацька і румунська емігрантські антирадянські групи. Видавалася газета «За самостійність» ${ }^{107}$. Наприкінці листопада 1947 р. Інтернаціонал Свободи формально об’єднався 3 АБН та «Лігою захисту прав народів Східної Свропи на самовизначення» (інша назва «Прометей») ${ }^{108}$. Було проголошено утворення єдиної організації - «Антибільшовицька ліга звільнення народів». Однак, через численні внутрішні протиріччі, вона виявилася нежиттєздатною ${ }^{109}$.

У той час Орест з сім'єю мешкав в квартирі на другому поверсі будинку за адресою: Баварія-Рінг, $12^{110}$. На початку 1948 р. Зибачинський підготував доповідь «Internationale der Freiheit. Die Konföderation der Völker des Interkontinentes»» ${ }^{11}$, а 16 липня того ж року увійшов до складу Комісії закордонних справ уряду УНР $(\text { м. Мюнхен) })^{112}$. Однак уже 27 червня 1949 р. на Другій сесії УНР-ради в м. Лямпгайм (Швабія, Західна Німеччина) Ореста вивели зі складу фракції ПУН ${ }^{113}$, а його місце зайняв Борис Суховерський ${ }^{14}$. Нового призначен- ня не довелося чекати довго. Уже в грудні того ж року на першому засіданні «Спілки Українських журналістів» Ореста обрали відповідальним за зв'язок з іноземною пресою ${ }^{115}$.

У квітні 1950 р. сім'я Зибачинських емігрувала до Австралії ${ }^{16}$ і оселилася в Сіднеі ${ }^{117}$. Перші роки Орест працював звичайним робітником. Лише згодом йому вдалося налагодити співпрацю з Дослідницькою фундацією імені Олега Ольжича. У 1978 - 1979 рр. Орест виїжджав до Канади, де редагував в Торонто часопис «Новий шлях» ${ }^{118}$. Увесь вільний час він присвячував поглибленню своїх гуманітарних знань. Творчий спадок Зибачинського дійшов до нас у низці політикофілософських праць ${ }^{119}$ : «Свободарність» (Сідней, 1955), «Інтегральна революція» (Мюнхен, 1960), «РенесансРеформація-Революція» (Чикаго, 1968), «Свободарний маніфест» (1978, Вінніпег), «Меч духа» (Вінніпег, 1980), «Містерія свободи» (Канберра, 1985), «Воля до свободи» (Сідней-Париж, 1988) $)^{120}$. Поряд із чоловіком публіцистичною працею в щомісячному журналі Союзу українок Америки «Наше життя» займалася Марта Зибачинська ${ }^{121}$.

Доволі трагічно складалася доля родини Ореста. Брата Мирослава у лютому 1942 р. арештувала румунська поліція та відправила 2 квітня до в'язниці в Яссах ${ }^{122}$. Після звільнення у серпні 1944 р. він переїхав до Бухареста, де 7 травня 1945 р. був арештований уже органами військової контррозвідки «Смерш» ${ }^{123}$. Після звільнення у січні 1956 р. 3 таборів ${ }^{124}$, виїхав до Бухаресту ${ }^{125}$. Звідти, на запрошення материної сестри Олени ВалднКобинської, емігрував в США ${ }^{126}$. O. Lysenko, V. Serhiichuk, Kyiv, Instytut istorii NAN Ukrainy, 2009, P. 69 [in Ukrainian].

${ }^{101}$ HDA SBU, F. 65, Spr. C-11861, Ark. 11 [in Russian].

${ }^{102}$ Ibid, F. 2, Spr. 2376, Ark. 174, 199 [in Russian].

${ }^{103}$ Ibid, F. 2, Spr. 2543, Ark. 5 [in Russian].

${ }^{104}$ Ibid, F. 2, Spr. 2194, Ark. 126 [in Russian].

${ }^{105}$ Ibid, F. 65, Spr. C-11861, Ark. 39 [in Russian].

${ }^{106}$ Ibid, F. 2, Spr. 1495, Ark. 27 [in Russian].

${ }^{107}$ Ibid, F. 2, Spr. 2543, Ark. 1-2 [in Russian].

${ }^{108}$ Tsentralnyi derzhavnyi arkhiv zarubizhnoi ukrainiky (TsDAZU) [State central archive of foreign ukrainika], F. 57, Op. 1, Spr. 3, Ark. 1 -11 [in Ukrainian].

${ }^{109}$ HDA SBU, F. 13, Spr. 372, T. 101, Ark. 294-295 [in Russian].

${ }^{110}$ Ibid, F. 65, Spr. C-11861, Ark. 186 [in Russian].

${ }^{111}$ TsDAZU, Op. 1, Spr. 5, Ark. 1-8 [in German].

${ }^{112}$ HDA SBU, F. 2, Spr. 2541, Ark. 36 [in Russian].

${ }^{113}$ Ibid, F. 2, Spr. 2542, Ark. 100 [in Russian].

${ }^{114}$ Ibid, F. 2, Spr. 2543, Ark. 160 [in Russian].

${ }^{115}$ Ibid, F. 65, Spr. C-11861, Ark. 63 [in Russian].

${ }^{116}$ Ibid, F. 65, Spr. C-11861, Ark. 41 [in Russian].

${ }^{117}$ Ibid, F. 2, Spr. 2542, Ark. 8 [in Russian].

${ }^{118}$ Ukrainska zhurnalistyka $v$ imenakh [Ukrainian journalism by names]. Materialy do entsyklopedychnoho slovnyka. Red. M. Romaniuk, Lviv, 1997, P. 100-101 [in Ukrainian].

${ }^{119}$ Husar Yu. «Ideoloh vyzvolnykh zmahan ukrainskoho narodu» [«Ideologist of the Ukrainian nation liberational struggle»]: [15 travnia 100 rokiv vid dnia narodzhennia publitsysta, filosofa Oresta Rudolfovycha Zybachynskoho], Bukovynske viche [Bukovinsky meeting], 2012, 11 travnia, P. 3.

${ }^{120}$ Zybachynskyi O. Svobodarnist. Esei na chuzhyni [Svobodarnist. Essays from a foreign land], Sidnei, 1955, 84 p.; Zybachynskyi O. Intehralna revoliutsiia [Integralna revolution], Miunkhen, 1960, 341 p.; Zybachynskyi O. Renesans - Reformatsiia - Revoliutsiia [Renaissance - Reformation - Revolution], Sidnei-Chykaho, Samostiina Ukraina, 1969, 88 p.; Zybachynskyi O. Svobodarnyi manifest. Prohrama novoi doby [Svobodarnist manifesto. The program of a new era], Toronto, 1978, 46 p.; Zybachynskyi O. Mech dukha. Komentar [Sword of the spirit. Comment], Vinnipeh, Tryzub, 1980, 112 p.; Zybachynskyi O. Volia do svobody. Dumky pro svit, liudynu y absoliut [The will to freedom. Thoughts about the world, human and absolute], Sidnei-Paryzh, Ukrainske slovo, 1988, $142 \mathrm{p}$ [in Ukrainian].

${ }^{121}$ Zybachynska M. Styl zhyttia chy vykhovannia ? [Lifestyle or upbringing?] Nashe zhyttia [Our life], Filadelfiia, 1952, Ch. 9, P. 4; Zybachynska M. Na sud zhyttia! [To the trial of life!] Nashe zhyttia [Our life], Filadelfiia, 1953, Ch. 1, P. 27 [in Ukrainian].

${ }^{122}$ HDA SBU, F. 65, Spr. C-11861, Ark. 107 [in Russian].

${ }^{123}$ Ibid, F. 2, Spr. 2376, Ark. 225-291[in Russian].

${ }^{124}$ Ibid, F. 2, Spr. 2742 , Ark. 118 [in Russian].

${ }^{125}$ Ibid, F. 1, Spr. 1630, Ark. 28 [in Russian].

${ }^{126}$ Ibid, F. 65, Spr. C-11861, Ark. 26 [in Russian]. 
27 листопада 1948 р. в чернівецькій лікарні помер батько Ореста $^{127}$, а матір переїхала до свого родича Олексія Киселиці в с. Бергомет Вижницького р-ну ${ }^{128}$. Звідти 19 червня 1950 р. органи МДБ виселили іï та тестя Ореста до будинку інвалідів в Каргасокський р-н Томської обл. (Росія) ${ }^{129}$.

У полі зору органів КДБ опинилися й інші родичі Ореста. Довідка від 16 грудня 1954 р. інформувала, що тітка по матері - Оделія Кисилиця працювала в художньому комбінаті м. Чернівці. Двоюрідна сестра - Ляля МосікевичКисилиця переїхала до Румунії. Дядько по батьку - Минодор Зибачинський працював адвокатом в м. Сучава (Румунія). Тітка дружини - Анна Кравчук проживала в с. Лужани Кіцманського р-ну, а двоюрідна сестра по батьку - Аглая Гловацька мешкала в Чернівцях. ${ }^{130}$

Водночас радянські органи держбезпеки не забували й про Ореста. Орієнтуванням УМДБ № 4/207 від 10 квітня 1951 р. його оголосили у розшук та завели агентурну справу «Волоцюги» ${ }^{131}$. Не припинялися заходів із компрометації Зибачинського в радянській пресі ${ }^{132}$. Йому приписували співпрацю з комісарами Чернівецького відділення Сигуранци - Тироном, Ротенбергом і Савицьким), а також німецьким Абвером. Закидала шахрайство та авантюризм. Стверджували, нібито Зибачинський отримав від банкіра Лутингера та промисловця Шиндлера великі пожертви. Завдяки цим коштам придбав в Чернівцях розкішний будинок та «жив на широку ногу» ${ }^{133}$.

Незважаючи на постійне переслідування ворогами, Оресту вдалося прожити довге й насичене життя. Він дочекатися здобуття Україною незалежності та помер 15вересня 1993 р. в Сіднеї ${ }^{134}$. У некролозі від Центрального Об'єднання Буковинських Українців в ЗСА (США) цитувалися слова Ореста: «Світ пройшов - української людини не знайшов. На межах континентів вона ще дозріває між ковадлом Заходу і молотом Сходу. Концентрах - іiі колиска. Рвати пута - iї шлях. Воскресати свободу - iї Доля... Колись серце України стане серцем Світу!».

Висновки. Аналізуючи життєвий шлях Ореста Зибачинського, можна стверджувати, що він був одним із чільних діячів Проводу Українських Націоналістів. Заснував перші осередки ОУН на Буковині та Донбасі. Створив «Закордонний центр» в Бухаресті та Інтернаціонал Свободи у Мюнхені. Впродовж року очолював Волинський інспекторат ПУН. Виступив одним із ініціаторів створення похідної групи «Пума». У різний час був учасником «мельниківського» підпілля у Києві, Миколаєві, Запоріжжі, Львові та інших містах. 3'ясовано, що Орест Зибачинський не приймав участі в створенні та діяльності Буковинського куреня. Розбудовуючи підпільну мережу на Донбасі, він опирався на українську інтелігенцію, а не на поліцію. Поряд із активною участю в українському визвольному русі, Орест Зибачинський залишив нам значний творчий спадок, який не втратив актуальності й нині.

Пропозиції. Непересічна постать видатного чернівча- нина заслуговує більш детального наукового дослідження, не передбаченого форматом статті. У перспективі життя та творчість Ореста Зибачинського може стати темою окремого документального фільму або й книги.

Antoniuk Ya. Life story of Orest Zybachynsky (1912 - 1993). The aim of the research is to study the life story of Orest Zybachynsky and to reveal his role in the Ukrainian liberation movement. Methodological basis of the study relies on the historicism principle, which requires consideration of all events in accordance with specific historical circumstances. Additionally, the objectivity principle is used, which involves support of facts in their true meaning. Particular scientific methods are applied such as historical research approaches: chronological, logical, retrospective, comparative and simulation of events. The scientific novelty of the article results is uncovering of the previously unknown pages of Orest Zybachynsky life and clarifications on many facts of his biography well-known by researchers. The aim is achieved due to the revealing and introduction of the archival documents to the scientific documents' circulation. These documents are mainly situated in the funds of the Branch State Archive of the Security Service of Ukraine. Conclusions. Generally, the analysis of Orest Zybachynsky life has confirmed that he had been one of the major figures of the Ukrainian Nationalists Leadership. He founded and developed the first OUN cells in Bukovina and Donbas regions. He created the «Overseas Center» of the PUN in Bucharest and the International of Freedom (IS) in Munich. He headed the Volyn Inspectorate of the OUN (m) for a year. He became one of the initiators of the «Puma» group of propaganda creation. During numerous periods, he had been participating in the "Melnykivtsi» underground movement in Kyiv, Mykolaiv, Zaporizhia, Lviv and other cities. It is clarified that Orest Zybachynsky was not engaged into creation and activities of the Bukovyna Kurin'. In addition, he relied on the Ukrainian intelligentsia, and not on the police, while building a clandestine network in Donbas region. Along with his active participation in the Ukrainian liberation movement, Orest Zybachynsky left us significantly creative heritage that has not lost its relevance even nowadays. His remarkable and prominent figure deserves a more detailed scientific study which is not determined by this article type. In the future, his life and work can be the subject of a separate documentary film or a book.

Key words: Chernivtsi, the community, «Zalizniak», the OUN underground, PUN, «Melnykivtsi», campaign «Puma» group, Donbas, International of Freedom.

Ярослав Антонюк - кандидат історичних наук, співробітник Галузевого державного архіву Служби безпеки України. Коло наукових інтересів: украӥнський визвольний рух у ХХ столітті. Автор 87 наукових публікачій, в т. ч. 4-х моногpapiǔ.

Yaroslav Antoniuk - PhD of historical sciences, an employee of the Branch State Archive of Security Service of Ukraine. The circle of scientific interest is Ukrainian liberation movement in the $X X$ century. He is the author of 87 scientific publications, including 4 monographs.

Received: 15.11 .2018

Advance Access Published: December, 2018

(C) Ya. Antoniuk, 2018

\footnotetext{
${ }^{127}$ Ibid, F. 2, Spr. 1495, Ark. 28 [in Russian].

${ }^{128}$ Ibid, F. 2, Spr. 1495, Ark. 104 [in Russian].

${ }^{129}$ Ibid, F. 65, Spr. C-11861, Ark. 5 [in Russian].

${ }^{130}$ Ibid, F. 2, Spr. 2543, Ark. 7-8 [in Russian].

${ }^{131}$ Ibid, F. 65, Spr. C-11861, Ark. 90 [in Russian].

${ }^{132}$ Ibid, F. 1, Spr. 1630, Ark. 28 [in Russian].

${ }^{133}$ Zinchuk Ya. Pidstupnyi alians. Ukrainski burzhuazni natsionalisty i sionisty - virni prysluzhnyky imperializmu [Tricky alliance. Ukrainian bourgeois nationalists and Zionists - faithful servants of imperialism], Radianska Bukovyna [Soviet Bukovyna], 1974, 6 hrudnia, P. 3; Pavliuk V. Za shmat hnyloi kovbasy [For a piece of rotten sausage], Molodyi Bukovynets [Young Bukovinets], 1979, 23 travnia, P. 3 [in Ukrainian].

${ }^{134}$ Orest Zybachynskyi. Vichna yomu pamiat! [Orest Zybachynsky. Eternal memory to him!], Svoboda [Liberty], 1993 , 18 veresnia, P. 3 [in Ukrainian].

${ }^{135}$ Orest Zybachynskyi. Vichna tobi pamiat ! [Orest Zybachynsky. Eternal memory to you!], Svoboda [Liberty], 1993, 5 zhovtnia, P. 3 [in Ukrainian]. 